Most of the correlations between the variables studied were small except for two of them which were highly significant : on the one hand, the correlation between fertility and prolificacy $(r=0.5 \mathrm{I})$ showed that culling of the poorly fertile boars improved the litter size, on the other hand, the highly significant correlation between the mean volume of the ejaculate and the total number of spermatozoa $(r=0.50)$, despite the poorness of spermatozoa in the second half of the ejaculate, emphasizes the relationship between the factors stimulating the spermatogenesis and the production of the accessory glands.

\title{
TECHNOLOGIE DE LA CONSERVATION DE LA SEMENCE DE VERRAT: ÉTUDE «IN VITRO »
}

\author{
M. PAGUIGNON, D. MERGOUNIS*, M. COUROT** \\ et F. DU MESNIL DU BUISSON* \\ Institut Technique du Porc, \\ 149 , vue de Bercy, \\ 75579 Paris Cedex 12 \\ * Station Centrale de Physiologie animale, \\ Centre national de Recherches zootechniques, I. N. R. A., \\ 78350 Jouy en Josas \\ ** Station de Physiologie de la Reproduction, \\ Centre de Recherches de Tours, I. N. R A., \\ B.P. 1, Nouzilly, 37380 Monnaie
}

\section{RÉSUMÉ}

Les auteurs présentent différentes techniques de préparation du sperme de verrat en vue de sa congélation en pellets sur glace carbonique et de sa conservation dans l'azote liquide. Ils étudient la survie des spermatozoïdes immédiatement après décongélation ou trois heures plus tard (incubation à $37^{\circ} \mathrm{C}$ ) en fonction de trois modes de refroidissement (A-B-C) entre $30^{\circ} \mathrm{C}$ et $5^{\circ} \mathrm{C}$ et de trois températures de glycérolisation $\left(30^{\circ} \mathrm{C}, 15^{\circ} \mathrm{C}, 5^{\circ} \mathrm{C}\right)$. L'abaissement de température de $30^{\circ} \mathrm{C}$ à $\mathrm{I} 5^{\circ} \mathrm{C}$ a lieu dans les conditions suivantes, $\mathrm{A}$ : en $5 \mathrm{~h}, \mathrm{~B}:$ en $\mathrm{I} \mathrm{h}$, puis maintien à $15^{\circ} \mathrm{C}$ pendant $4 \mathrm{~h}, \mathrm{C}$ : en I. h.

Pour les trois traitements, l'abaissement de $15^{\circ} \mathrm{C}$ à $5^{\circ} \mathrm{C}$ se fait en $\mathrm{I} h$.

L'éjaculat entier est centrifugé après la collecte à $28-30^{\circ} \mathrm{C}$ pendant $\mathrm{I} 5 \mathrm{mn}$ à $\mathbf{1} 900 \mathrm{t} / \mathrm{mn}$ $(800 \mathrm{~g})$. Le culot est alors dilué une première fois dans le rapport I vol. de culot de sperme $-\mathbf{2}$ vol. de dilueur. Une deuxième dilution a lieu ultérieurement avec la même quantité du même dilueur qui est alors additionné de glycérol au taux de $6 \mathrm{p}$. Ioo. On utilise un dilueur à base de jaune d'œuf et de glucose (Polge et al., 1970).

La glycérolisation faite à $1^{\circ} \mathrm{C}$ après $\mathrm{I}$ h ou $5 \mathrm{~h}$ de refroidissement (traitement $\mathrm{B}$ ) donne les mêmes résultats (p. Ioo de spermatozoïdes mobiles à la décongélation, $\mathrm{D}, 24,9 \mathrm{p}$. Ioo contre 25,9 p. Iоo,) (p. roo de spermatozoïdes mobiles après décongélation et $3 \mathrm{~h}$ d'incubation à $37^{\circ} \mathrm{C}, \mathrm{I}$, 
19,2 p. Ioo contre 19,7 P. Ioo. La glycérolisation faite à $5^{\circ} \mathrm{C}$ abaisse les résultats à la décongélation (D, I 9,7 p. Ioo contre 23,4 p. Ioo) mais n'a pas d'influence significative sur les résultats après incubation. La glycérolisation à $30^{\circ} \mathrm{C}$ n'a pas un effet significativement différent de celle opérée aux autres températures.

Le mode de refroidissement $B$ donne des résultats significativement supérieurs aux traitement A et C (D, 24,I p. Ioo contre I8,3 p. Ioo et $2 \mathrm{I}, 4$ p. Ioo) (I, I 7,6 p. Ioo contre II,5 p. Ioo et 13,5 p. I00).

La congélation de semence se trouvant à $I 5^{\circ} \mathrm{C}$, et non à $5^{\circ} \mathrm{C}$, provoque un abaissement du taux de survie des spermatozoïdes après décongélation ( 2 2, I p. IOO contre 2 I,9 p. IOO).

Les premiers résultats d'insémination artificielle sont encourageants, bien que de nombreux problèmes restent à résoudre : sur 9 truies inséminées à un moment très précis de l'œstrus avec du sperme congelé (traitement B), 8 ont été gestantes.

L'utilisation de cette technique de congélation pour l'insémination artificielle fait l'objet d'un brevet.

\section{SUMMARY}

TECHNOL, OGY OF BOAR SEMEN CONSERVATION : IN VITRO STUDY

The authors present different techniques for the preparations of boar semen to be frozen in pellets on carbon dioxide ice and preserved in liquid nitrogen.

The survival of spermatozoa was observed immediately after thawing or three hours later (incubation at $37^{\circ} \mathrm{C}$ ) according to three cooling methods (A-B-C) between $30^{\circ} \mathrm{C}$ and $5^{\circ} \mathrm{C}$ and three temperatures of glycerolization $\left(30^{\circ} \mathrm{C}, 15^{\circ} \mathrm{C}, 5^{\circ} \mathrm{C}\right)$. Lowering of the temperature from $30^{\circ} \mathrm{C}$ to $15^{\circ} \mathrm{C}$ took place in the following conditions: A within $5 \mathrm{~h} ; \mathrm{B}$ within $\mathrm{I} \mathrm{h}$ and maintenance at $\mathrm{I} 5^{\circ}$ for $4 \mathrm{~h}$; $\mathrm{C}$ within $\mathrm{I} \mathrm{h}$. For the three treatments, lowering of the temperature from $15^{\circ} \mathrm{C}$ to $5^{\circ} \mathrm{C}$ lasted $\mathrm{I} \mathrm{h}$.

The entire ejaculate was centrifuged after collecting at $28{ }^{\circ} \mathrm{C}-30^{\circ} \mathrm{C}$ for $15 \mathrm{mn}$ at $1900 \mathrm{t} / \mathrm{minute}$ $(800 \mathrm{~g})$. The culot was then diluted first in the proportion I vol sperm culot/2 vol diluter. A further second dilution was made with the same amount of the same diluter to which was added 6 p. Ioo of glycerol. The diluter contained egg yolk and glucose (PolGE et al., 1970).

The glycerolization made at $15^{\circ} \mathrm{C}$ after $\mathrm{I} \mathrm{h}$ or $5 \mathrm{~h}$ cooling (treatment $\mathrm{B}$ ) gave the same results (p. Ioo of motile spermatozoa at thawing, D, 24.9 p. Ioo versus 25.9 p. I00) (p. Ioo of motile spermatozoa after thawing and $3 \mathrm{~h}$ of incubation at $37^{\circ} \mathrm{C}, \mathrm{I}, \mathrm{I} 9.2$ p. Ioo versus I9.7 P. Ioo). Glycerolization made at $5^{\circ} \mathrm{C}$ lowered the results at thawing (D, 19.7 p. Ioo versus 23.4 p. Ioo), but did not have any significant effect on the results after incubation. The effect of glycerolization at $30^{\circ} \mathrm{C}$ was not significatly different from that occuring at other temperatures.

The cooling method $B$ gave significantly higher results than treatments $A$ and $C(D$, 24. I p. IOO versus I 8.3 p. Ioo and 2 I.4 p. IOO), (I, I 7.8 p. Ioo versus II 5 p. Ioo and 13.5 p. IOO). Freezing of sperm from $15^{\circ} \mathrm{C}$ and not from $5^{\circ} \mathrm{C}$, caused a lowering of the survival rate of spermatozoa after thawing (I2.I p. Ioo versus 21.9 p. IOO).

The first results of I. A. are encouraging although many problems have to be resolved : 8 out of 9 sows inseminated with frozen sperm (treatment B) at a very precise moment of the œestrus became pregnant.

The utilization of this technique of sperm freezing for IA has been patented. 